\title{
The Ideological Analysis of The Guardian News about The Moving of Indonesian Capital City
}

\author{
Vidya Mandarani ${ }^{1}$, Niko Fedianto ${ }^{2}$ \\ \{vmandarani@umsida.ac.id\} \\ ${ }^{1,2}$ Univesitas Muhammadiyah Sidoarjo, Indonesia
}

\begin{abstract}
There are many media in the world preaching about issues in Indonesia, with news trending topics not only at the national level but also at the international level, which is the planned move of the Indonesian capital. One of the world's media who received news about the movement of the capital of Indonesia is The Guardian. The Guardian is a British daily newspaper. To analyze the news presented by The Guardian, framing analysis theory by Robert Entman is used to determine the selection of issues displayed in the news. The data is from The Guardian news on $26^{\text {th }}$ August 2019 edition. Entman divides framing into four elements as follows: First, Define Problems; Second, Diagnose cause; Third, Make moral judgment, and Fourth, Treatment recommendation. The result shows The Guardian presenting government representatives and environmental activists who have different views regarding the importance of moving the capital city and the economic impact. The ideological views of the article brings to the decision about moving the capital city.
\end{abstract}

Keywords: Ideological Analysis; Indonesia Capital City; The Guardian

\section{INTRODUCTION}

Studying the development of mass media in the world can provide benefits, among which is that we can know and understand the various types of mass media and the impact of the presence of the internet for mass media in carrying out their functions and roles to the public. When we talk about the rapid of the information in Indonesia known by all of the people in the world, it is all because of the very fast media networks can be easily accessed. Some media in the world preaching about issues in Indonesia, with news trending topics not only at the national level but also at the international level, is the planned move of the Indonesian capital. One of the world's media who received news about the movement of the capital of Indonesia is The Guardian. The Guardian is a British daily newspaper. It was founded in 1821 as The Manchester Guardian, and changed its name in 1959. In 2006, the US-based Society for News Design chose The Guardian as the world's best-designed newspapers-from among 389 entries from 44 countries [1]. The Guardian is very much a reference of readers throughout the world so that it is the subject of research in this study.

To analyze the news presented by The Guardian, framing analysis theory by Robert Entman is used to determine the selection of issues displayed in the news. There are two Entman Version Framing Media Elements [2], namely the selection of issues and highlighting certain aspects of an issue. In writing news, journalists choose certain aspects of an issue. In 
more detail and consistency, Entman offers a way to uncover the power of a communication text. Entman points out that framing basically refers to reporting definitions, explanations, evaluations and recommendations in a story to emphasize a certain frame of mind for events. To find out the framing of the media, Entman can describe how journalists interpret an event. Entman divides framing into four elements as follows: First, Define problems, this element is the main frame that emphasizes how events are interpreted differently by journalists, and therefore each journalist has a different perspective. Second, Diagnose cause (estimate the cause of the problem), this is used to frame who is considered as an actor of an event. This element can be (what) and (who). This means that how the event is understood certainly determines what and who is considered as the source of the problem. Therefore, the problem is understood differently, then the cause of the problem will be understood differently, too. Thus, defining the source of this problem explains who is considered the perpetrator and the victim. Third, Make moral judgment, this element refers to what moral value is used to legitimize an action in the event by prioritizing the molar value, then this element is used to justify and provide an assessment of the event that occurred. Fourth, Treatment recommendation (emphasizing completion), this element is used to assess whether the journalist will choose to solve the problem. This solution is very dependent on how events can be seen and who is seen as the cause of the problem [3].

Ideology is never separated from the ability to manipulate the reader toward an ideology. Ideology has two opposite meanings. Positively, ideology is perceived as a worldview that states the values of certain social groups to defend and advance their interests. While negatively, ideology is seen as a false awareness, which is a need to commit fraud by distorting people's understanding of Sobur's social reality [4].

Several studies were carried out using the Entman theory, conducted by Pratiwi, regarding Republika and BBC News on LGBT reporting by using Framing Robert N. Etnman's model; there are several conclusions, namely; First, Republika tries to make LGBT reporting tend to prioritize Islamic ideology, as evidenced by the reports published by Republika always quoting the attitude of the minister of religion and assembly religion. Secondly, BBC News from the standpoint of the LGBT problem, is more neutral, does not question religion but rather humanizes people and there are even figures who are pro with LGBT [5]. Pratiwi research shows that the media has a different way to express the same issue about LGBT; both try to package the contents of the news with language that is smooth and wise. Based on this Pratiwi's research, this research conducted research about the media "The Guardian" as the international media to see the Indonesian issue.

The same theory by Robert Entman with the different subject of study taken by Anggraini, that analyzes kompas.com and sindonews.com on the period of $16^{\text {th }}$ October 2017 up to $21^{\text {st }}$ October 2017 framing the news related to food governance in Indonesia using Entman Framing Analysis [6]. The result of Anggraini's research that the two online media emphasize issue about the food governance management system. However, the assertion of the two news is different; kompas.com tends to build and develop the village and farmer regeneration aspect, while sindonews.com emphasized reinforcement of the management system of food governance. Anggraini's research focuses on the issue of food sovereignty governance, and it can be concluded that both news stories deliver news with an emphasis on different issues.

The ideological research related to the presidential election on July 9, 2014, by TV One and Metro TV, Anggoro found that the media alignments with the presidential candidate pair in the broadcast content were broadcast. TV One framed the news program that portrayed Prabowo and Hatta Rajasa as the winners of the 2014-2019 elections while Metro TV's Joko Widodo and Jusuf Kalla as the winners of the 2014-2019 elections [7]. The Anggoro research 
shows that TV One dan Metro TV have a different ideology in presenting the news about the presidential election. In line with this research that the ideology is really needed to know because the news has its ideological issues.

\section{METHOD}

The approach used in this study is a descriptive qualitative approach, the qualitative approach is a research procedure that produces descriptive data in term of words, either written or spoken from people (respondents or objects) and their perceivable attitudes [8]. This research is about the analysis of Indonesia to move the capital city to another Island from The Guardian News.

Framing analysis is an analysis to find out how the media frame the issue of news. The use of Robert Entman's framing analysis theory is purposed to reveal how the framing of the movement of the capital city. The data is from The guardian news on $26^{\text {th }}$ August 2019 edition. This article was chosen because of the two articles published by the guardian, the article entitled, Why is Indonesia moving its capital city? Everything you need to know, structurally, the reporting more represented the issue analyzed using Robert Entman's theory.

\section{RESULT AND DISCUSSION}

Entman's framing has four schemes to determine news framing by The Guardian journalist about Indonesia will displace Jakarta as the capital city. Here is the analysis:

Identifying the problem: Indonesia's President has already announced the displacement of the capital city to East Kalimantan province if the House of Representative has approved the bill. In this case, Widodo is optimist that moving capital city just cost 466 trillion rupiahs.

"Widodo said moving the capital would cost 466 trillion rupiahs $(\$ 32.7 \mathrm{bn})$, of which the state would fund $19 \%$, with the rest from public-private partnerships and private investment."

"This is a plan that has been suggested by various Indonesian presidents over the decades, but it looks like the move will finally, actually happen. Widodo said the government would prepare a bill to be considered by the House of Representatives. If approved, construction could start next year."

Interpreting causally: The Guardian reported that Indonesian government does not have a main concern on why Jakarta must be replaced to a-yet-to-be-built city in East Kalimantan and tried to lessen the emphasize upon how Indonesian Government only covers $19 \%$ of relocation bill, while giving Private Sectors the rest of bill portions. However, the journalist instead gives some of the environmental reasons like the explosion of new apartment buildings, shopping malls, government offices which impacted serious environmental issues in Jakarta. That is why relocation is needed to address inequality and relieve some of the burdens on Jakarta. Further, Minister National Development of Indonesia, Bambang Brodjonegoro, gives a hope that relocation will have a positive environmental impact such as rehabilitate protected forests.

"We will not disturb any existing protected forest; instead, we will rehabilitate it," the planning minister Bambang Brodjonegoro, was reported as saying in the South China Morning Post." 
Moral evaluation: Environmentalists stated that relocation is not a solution, it will just create a new environment problem in Kalimantan if it is not carefully handled.

"Environmentalists have said the relocation needs to be carefully handled or it will result in leaving one ecologically damaged area, only to create another."

Recommending a treatment: As a form of impartiality, The Guardian journalist does not conclude the news with a recommendation or insert any official's opinion that can support one side, so that she just gives examples of countries that have already moved their capital city.

"A bit, but not unheard of. In 2005 Naypyidaw replaced Yangon as the capital of Myanmar. Like the proposed capital of Indonesia, Naypyidaw was a planned city, as Canberra was when it became Australia's capital in 1911. Brasília, another planned city, replaced Rio de Janeiro as the capital of Brazil in 1960, moving the capital to a more central location in the country."

The approach of Robert N. Entman's News Framing over the news "Indonesia will displace Jakarta as capital city" [9] shows that the direction of The Guardian in this matter is through government representatives and environmental activists who have different views regarding the importance of moving the capital city, and the impact that will have on the environment in Kalimantan, because the movement of central government will increase the population and impact massive new buildings. Although, the government has explained that it will be only 40,000 hectares and will not disturb mining activities as well as rainforest habitat.

From the result of the analysis, it can be seen that the issue is about the urgent problem in the capital city, make the government move. The moving is because of the expansion of having a better condition of Indonesia for the other Island. The ideological arise from a particular set of material interests or, more broadly, from a specific class or group, which is in this term Indonesia government, who have different views regarding the importance of moving the capital city. So many positive reasons from the article brings to the decision about the moving the capital city.

\section{CONCLUSION}

The conclusion can be taken from the analysis using Robert Entman Framing analysis theory, form the identifying the problem, interpeting causally, moral evaluation, and recommending treatment, the issue of the news regarding the importance of moving the capital city and the impact that will have on the environment in Kalimantan, because the movement of central government will increase the population and impact to the economic distribution. The government, with all the consideration as the decision maker has the consideration why the capital city must move to Kalimantan.

\section{REFERENCES}

[1] A. Beaujon, "Guardian among 'World's Best-Designed Newspapers' in SND contest," Poynter., 2014.

[2] Eriyanto, Analisis Framing (Konstruksi, Ideologi dan Politik Media). Yogyakarta: LkiS, 2002.

[3] R. M. Entman, "Framing: Toward Clarification of A Fractured Paradigm," J. Commun., vol. 43, no. 4, p. 51, 1993.

[4] A. Sobur, Analisis Teks Media. Bandung: PT. Remaja Rosdakarya, 2015. 
[5] A. Pratiwi, "Konstruksi Realitas dan Media Massa (Analisis Framing Pemberitaan LGBT di Republika dan BBC News Model Robert N. Entman)," Thaqofiyyat (Jurnal Bahasa, Perad. dan Inf. Islam., vol. 19, no. 1, pp. 50-71, 2018.

[6] D. Anggraeni, "Entman Framing Analysis of Food Governance in Online Media," J. Messenger, vol. 10, no. 1, pp. 113-123, 2018.

[7] A. D. Anggoro, "Media, Politik dan Kekuasaan (Analisis Framing Model Robert N. Entman tentang Pemberitaan Hasil Pemilihan Presiden 9 Juli 2014 di TV One dan Metro TV)," J. Aristo, vol. 2, no. 2, pp. 25-52, 2014.

[8] J. M. Lexy, Metodologi Penelitian Kualitatif. Bandung: PT. Remaja Rosdakarya, 2000 .

[9] K. Lyons, "Why is Indonesia moving its capital city? Everything you need to know," The Guardian, Indonesia, 2019. 